It was a great grief to his many patients when in 1950 he retired to the bird sanctuary he had created with the enthusiastic co-operation of his wife at Culterty, near Newburgh, some 12 miles north of Aberdeen. Throughout his long professional life it is doubtful if "H.E.S." ever made an enemy. He was blessed with an even temperament and it was rare to hear him raise his voice even to the most trying patient. He was an excellent teacher, never attempting to impart too much knowledge at a time. His hospital notes were brief but adequate and written in large exquisite Italian hand-writing that has made their reading a joy to the next generation of ophthalmologists. To these younger people he endeared himself by his charm of manner and his readiness to advise and help in all difficulties. No one ever sought help in vain, but his most outstanding quality was his loyalty, and that his colleagues could always count on. One sometimes wondered what loss the diplomatic service sustained by his fortuitous entry into ophthalmology. No gloomy prognosis given to a patient sounded half so bad when phrased by "H.E.S."

In addition to a full professional life Edgar Smith had many cultural interests. Ornithology in Scotland owed much to him, and his Newburgh Bird Sanctuary became a Mecca for bird lovers as well as for his many friends. It is sad to recall that during the last few years of his life as a semi-invalid he had mainly to be content to view a corner of it from the windows of a sick-room. Last autumn he was advised for the sake of his health to find a new house away from the sea. The purchase of Culterty by Aberdeen University for research by the Department of Natural History comforted him a little at having to leave the sanctuary he had built up with such loving care. He remarked lately that to leave Culterty would break his heart and indeed it has almost seemed so, as he survived the uprooting by only two weeks. His many friends, ophthalmic and otherwise, will ever cherish the memory of a singularly selfless and warm-hearted man. He was predeceased by his wife some 5 years ago.

\title{
JOHN DEMPSTER Fraser
}

Dr. John Dempster Fraser, T.D., died suddenly, on May 21, 1956, while giving evidence in court, in his 43rd year.

Dr. Fraser was a native of Glasgow, and graduated M.B., Ch.B., with Honours at that University in 1936. After holding medical and surgical posts at the Western Infirmary, he entered ophthalmology as a resident with the late Professor Ballantyne in the Tennent Institute, and joined the staff of that department and of the Glasgow Eye Infirmary just before the outbreak of war in 1939. As a serving territorial officer, he was mobilized as medical officer to the 6th Batallion the Highland Light Infantry, in 1939, and in 1940 was posted as ophthalmic specialist to the Military Hospital at Hong Kong, where he was a prisoner-of-war from 1941-1945. He was mentioned in dispatches for his services in the hospital during this period.

On his return to Scotland after the war, it is characteristic of the man that he took up duty at his hospitals the day after he arrived home.

In 1949 he became a Fellow of the Royal Faculty of Physicians and Surgeons, and, at the time of his death, he was a surgeon in charge of wards at the Glasgow Eye Infirmary, and also acted as pathologist. He had recently taken over as surgeon in charge of the orthoptic school at the Eye Infirmary, and had joined the British Orthoptic Board.

He was one of these willing and friendly people on whose shoulders secretaryships naturally fall. At the time of his death, he was Secretary of the Scottish Ophthalmological Club, which is but the last of a series. An able ophthalmologist, and a genuine and cheerful colleague, his passing is a severe loss to ophthalmology in Glasgow.

He is survived by a widow and two young children. 